ORIGINAL SCIENTIFIC WORK

378.147::811.111]:004(497.115)"2013"

378.018.43(497.115)

DOI: $10.5937 /$ ZRFFP45-9388

ANITA V. JANKOVIĆ ${ }^{1}$

UNIVERSITY OF PRIŠTINA WITH TEMPORARY HEAD-OFFICE

in KosovsKa Mitrovica, Faculty of PhiLOSOPHY

DEPARTMENT OF ENGLISH LANGUAGE AND LITERATURE

\title{
BLENDED LEARNING AT THE FACULTY OF PHILOSOPHY IN KOSOVSKA MITROVICA AND WHY IT FAILED: A CASE STUDY ${ }^{2}$
}

ABSTRACT. Systematic implementation of the blended learning approach in teaching and learning of English as a foreign language was first initiated at the Faculty of Philosophy in Kosovska Mitrovica in October 2013 within the framework of the Tempus BLATT project, delivering the blended course of Contemporary English Language 1 for the first year students at the Department of English Language and Literature in two consecutive school years. The instructional design of the course presented a mixture of delivery modes and learning styles under the scope of strategically planned use of online learning tools fused with the features of the brick-and-mortar classroom.

The aim of this paper is threefold: (1) to perform a review of available literature in search of a comprehensive list of success factors for the institutional adoption of blended learning in higher education as well as the resulting obstacles; (2) to measure conditions under which the blended learning was implemented at the Faculty against the found factors; (3) to present the results of the evaluation study on the quality of the course, the student satisfaction, and the teachers' perceptions of the blended mode of delivery.

KEY WORDS: blended learning, institutional adoption, sustainability, success factors, barriers, transformation, evaluation.

anita.jankovic@pr.ac.rs

This paper is the result of the study performed within the framework of the Tempus BLATT project 530266-TEMPUS-1-2012-1-XK-TEMPUS-JPCR (http://www.tempusblatt.pr.ac.rs/).

Рад је примљен 1. новембра 2015, а прихваћен за објављивање на састанку Редакције 3борника одржаном 25. децембра 2015. 
"In my estimation, more misery has been created by reformers than by any other force in human history."

Frank Herbert "Heretics of Dune"

\section{INTRODUCTION}

The aim of this paper is threefold: (1) to perform a review of available literature in search of a comprehensive list of success factors for the institutional adoption of blended learning in higher education as well as the resulting obstacles; (2) to measure conditions under which the blended learning was implemented at the Faculty of Philosophy in Kosovska Mitrovica against the found factors; (3) to present the results of the evaluation study on the quality of the course, the student satisfaction, and the teachers' perceptions of the blended mode of delivery.

The European Commision proposes that the higher education institutions (HEIs) should revise their mission statements and policies in order "to increase the quality of content and of the learning experience through blended learning [...] and to overcome the systemic obstacles that still exist [...]" (European Commision, 2013, p. 7). In the field of educational research, the last few years have been marked by the transition of research focus from the benefits and drawbacks of blended learning (BL) to drivers and barriers of the institutional adoption of this approach. However, in their attempt to devise a framework for BL adoption at the institutional level, Porter and Graham (2015) have detected the scarcity of the research on the topic, emphasizing its importance for HEIs.

Although BL has many faces and often eludes precise definition ${ }^{3}$, this paper, accepts the definition provided by Graham (2006) that BL is a combination of online and face-to-face instruction. Such broad definition serves at the same time as one of the arguments that the paper attempts to make further down the road. Therefore, the term 'blended learning' will be used here in all its ill-defined glory. Systematic implementation of the BL approach in teaching and learning of English as a foreign language was first initiated at the Faculty of Philosophy in Kosovska Mitrovica in October 2013 within the framework of the Tempus project "Blended Learning: Advanced Teacher Train-

3 For an array of different definitions of blended learning and ratios of online and classroom time it entails, see Torrisi-Steele, 2011; Dziuban et al, 2004. 
ing" (BLATT), delivering the blended course of Contemporary English Language $1^{4}$ for the first year students at the Department of English Language and Literature in two consecutive school years.

Based on the survey of seminal works and empirical studies, as well as on the experience in implementing BL in foreign language teaching at the tertiary level, this paper intends to answer two important questions:

1) What factors lead to the successful implementation of the blended learning approach at a higher education institution?

2) What steps could have been taken to provide sustainability of the blended courses at the Faculty of Philosophy?

Therefore, the remainder of the paper is organized into four sections. First, it performs a review of available literature in search of a comprehensive list of success factors for the implementation of BL in higher education as well as the resulting obstacles. Second, the paper measures conditions under which the approach was implemented at the Faculty of Philosophy against the found factors by describing the steps of the transformation. The third section presents the evaluation study on the quality of the course, the student satisfaction, and the teachers' perceptions of the blended mode of delivery. Finally, the paper ends with a summary of the results and conclusions.

\section{SUCCESS FACTORS AND BARRIERS}

The research questions mentioned above determined the selection criteria for the literature review. The key terms for the Google Scholar search of published and peer-reviewed studies were: success/failure of blended learning, institutional adoption, teacher's perception, student satisfaction. The focus of the search was dual in nature; primarily, there is a selection of seminal works by authors well-established in the field (De Vries, 2005; Dziuban et al, 2004; Garrison \& Kanuka, 2004; Moskal et al, 2013; Porter \& Graham, 2015; Sharpe et al, 2006; TorrisiSteele, 2004) whose research would bring a wider perspective on the issue. Secondly, to ensure that the findings are grounded in practice, a range of empirical studies were included in the review. ${ }^{5}$

4 The online component of the course is available for guest access at http://bit.ly/ SEJ1Virtualclassroom

5 Papers that do not have open access have been excluded from this review. 
The success factors are examined here from a perspective that Romiszowski (2004, p. 9) calls "macro issues of diffusion of innovation" meaning that factors concerning advantages and disadvantages of $\mathrm{BL}$ are to be disregarded. As a continuation of the study of such micro level factors ${ }^{6}$, this paper posits that BL has a positive, even transformative effect on student performance and learning outcomes. Accordingly, it will only observe factors that influence institutional mission and policy change as mentioned in the Brussels communiqué at the beginning of the paper (European Commission, 2013).

Current research in the field is aimed at designing a framework for institutional adoption at the tertiary level of education. The aspects of change are various and often hide under different names with different authors, but the categories that most agree on are: policy, support, and evaluation. Under these broad categories, this study will examine the varieties individual researchers have identified.

The importance of institution-wide policy or strategy for the adoption of the BL approach is the most emphasized factor. The university leadership is faced with the need to rise up to the challenges of collaborative learning and quality assurance in the connected world (Garrison \& Kanuka, 2004). Abel (2005) reports that the top-down approach to BL can single-handedly ensure the sustainability of the practice and "growth of the grass-root sources" (p. 22). The advocacy for BL lies in institution's executive management whose right and responsibility is to formalize the aims and outcomes for its implementation (Moskal et al, 2013; Porter et al, 2014).

Moskal et al. (2013) see the beginning of the policy making with the definition of what BL means to a particular HEI and the development of the metalanguage to facilitate a discussion and the alignment of goals of all the stakeholders. Hande (2014) designates this stage as "concretization" playing into the need to have clear ideas of what is being done. In their review of UK literature and practice in 2006, Sharpe et al. conclude that the advantage of the term BL lies in its shifty nature and that it enables "staff to negotiate their own meaning" (p. 75). On the other hand, Royal at al. (2014), in their commentary on the semantics of blended learning, claim that „specialized terms often compel faculty to think of instructional approaches as a strict dichotomy, as opposed to a continuum that offers maximum flexibility" (p. 81). All in all, for a HEI that makes its baby steps in BL policy making, it is of vital importance to interpret and define the

6 See Jovanović et al., 2015. 
concept and develop linguistic tools within its own context. Royal's pitfall can be avoided in the later stages of the transformative development.

Many authors report that their studies have shown one significant characteristic of HEIs which successfully implemented BL, that is clear motivation, and consequently clear goals and objectives that arise from it (Abel, 2005; De Vries, 2005; Moskal et al, 2013). In addition, goals and objectives which are "highly contextualized and specific" to the given institution ensure a higher rate of sustainability (Sharpe et al, 2006). White (2007, p. 848) believes that the executive management faces a great challenge "in identifying the reality of the local circumstances and working with the existing strengths" when planning their policy. In accordance with this, De Vries (2005) suggests conducting an in-depth needs analysis of all the involved parties; furthermore, Thurab-Nkhosi (2013) identifies an opportunity here for the bottom-up approach by engaging students and the faculty in the process of assessing the situation in the field. Although transformative in nature, the BL approach and the policy that regulates it should align with the original institutional mission and be in service to students (Abel, 2005).

The final aspect of devising an institutional strategy is the assessment of the required resources that Garrison and Kanuka (2004) divide into three sets: financial, human, and technical. Hande (2004) refers to this aspect as coordination of resources. Face-to-face interaction characteristic for traditional course delivery is reliable, so the same is expected from the online instruction in BL. The smooth flow of teaching and learning in the virtual learning environment can be achieved by investing in reliable, accessible, and intuitive technology as well as in training the faculty in its usage.

Second important category in the process of successful adoption of the BL approach in tertiary education is the scaffolding that ensures smooth operations of all the gears in the machine. Three vital steps in the support of the change are: technical, professional, and student services. In the discussion of financial resources needed for the transformation, we mentioned the need for the upgrade of the technical infrastructure; minimally, it could be achieved by increasing the bandwidth and constructing or adapting the learning management system. Romiszowski (2004) suggests doing this in cooperation with the Informational Technology team to ensure the robust and efficient system. 
Garrison and Kanuka (2004) reference famous Canadian philosopher Marshal McLuhan and apply his trademark expression "Medium is the message" to education by saying that simple switch of the delivery medium would be futile, so we should redesign the instruction to fit the new medium. The surveyed studies agree on the utmost importance of the professional development and training of the lecturers for the blended instruction. In order to make the transition, Napier et al. (2011) confirm the vital role of proper teacher training. What is more, De Vries (2005) suggests a blended format for the actual development program ensuring a hands-on experience of the training.

Moskal et al. (2013) insist on having a learning specialist or an instructional designer to lead the development program and consult the teachers on creating the online content. Furthermore, the professional development program should be a norm throughout the process by having the teachers meet constantly and regularly to review their practice and plan together, to discuss issues of copyright and accessibility, to share new learning tools, and to accumulate examples of best practices and effective learning (Moskal et al, 2013; Jokinen \& Mikkonen, 2013; Porter et al, 2014).

The establishment of the comprehensive student services is also a milestone in supporting the process of institutional adoption of BL. "Hours of online learning opportunities can be blocked by something as simple as an expired password" (Moskal et al, 2013, p. 17). Romiszowski (2004) suggests online and phone technical support and mentoring as ways of easing students into the new medium. Student buyin is also guaranteed by a clear and transparent course catalogue that will/would inform them before the beginning of the semester which courses are blended, how heavy the blend is, what is expected from them on a weekly basis, etc. (Sharpe et al, 2006). Once the requirements are clearly communicated, help lines are established, and digital skills acquired, participation in the blended course becomes very easy (Hande, 2014; Harris et al, 2009).

To round off a successful adoption, ensure sustainability, and assure the quality of the courses, HEIs need to monitor and evaluate student satisfaction and performance, quality of teaching, reliability of technology, and effectiveness of administration and support (Garrison \& Kanuka, 2004). Sharpe et al. (2006) agree that it is crucial to assess institutional policy and course transformation, but also to disseminate the results of the assessment. Furthermore, Moskal et al. (2004) recommend instituting "structures for central, longitudinal data collection for purposes of tracking and assessment" (p. 18). Har- 
ris et al. (2009) add to the discussion with the remark that evaluation should be performed by all participants and include "standardized, reliable, and valid measures [...] to facilitate replication and appropriate comparison" (p. 159).

The discussion on barriers to faculty and institutional adoption of BL stems from the list of success factors presented here. Higher education can be very slow in adapting to change; therefore, there is no BL adoption without the faculty support and it is the teaching staff that reports most obstacles to successful implementation of the approach in the reviewed empirical studies. The list begins with the problem of the increased teacher workload and the change of their roles (Figure 1).

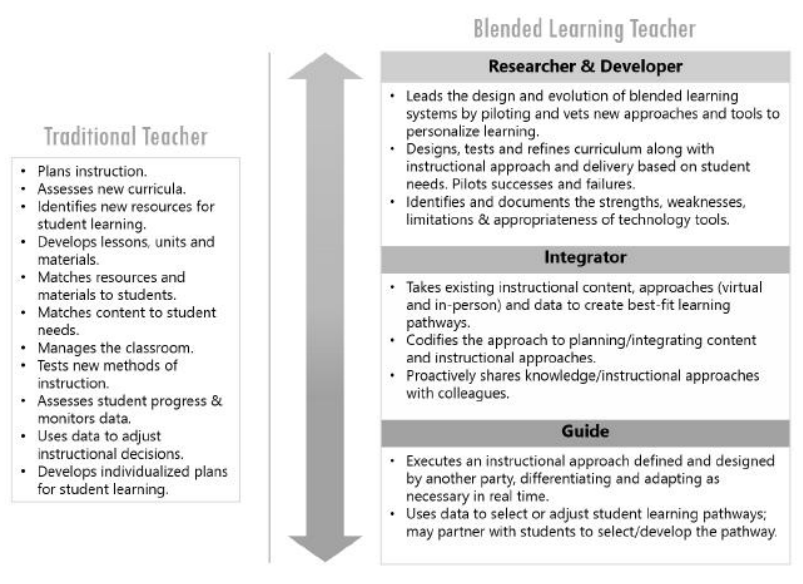

FIGURE 1 TEACHER ROLES ${ }^{7}$

Ocak (2011) reports the grievances of the academic staff about managing different roles in blended courses and inherently shouldering more responsibility. Porter and Graham (2015) also note the lack of time for creating online materials and participating in online forums. Number of students in a blended course makes up a significant factor; the instructor, already overloaded with face-to-face teaching and designing e-learning, now needs to interact with each individual student, assess their participation in the virtual learning environment and provide feedback, and very often serve as the first line of tech support (Sayed \& Baker, 2014; Shaqour, 2011). Finally, here are the main barriers back to back, for comparison.

7 Source: Reimagining Teaching in a Blended Classroom, 2014, pg 2. 


\begin{tabular}{|c|c|}
\hline INSTITUTIONAL LEVEL (ROMISZOWSKI, 2004) & FACULTY LEVEL (TSHABALALA, 2014) \\
\hline $\begin{array}{l}\text { - Poor internal marketing of courses and } \\
\text { events } \\
\text { - Lack of clear reward structure } \\
\text { - Failure to provide quality learning } \\
\text { equipment } \\
\text { - Failure to provide managerial feedback and } \\
\text { support of learning } \\
\text { - Failure to provide on-the-job training } \\
\text { - Failure to match Internet training to its } \\
\text { most appropriate purposes }\end{array}$ & $\begin{array}{l}\text { - Lack of policy with the guiding principles } \\
\text { for implementation } \\
\text { - Lack of faculty support ensuring effective } \\
\text { implementation } \\
\text { - Lack of technological and computer skills } \\
\text { - Large class size } \\
\text { - Inadequate technological resources }\end{array}$ \\
\hline
\end{tabular}

STATE OF AFFAIRS

This section presents circumstances under which BL was implemented at the Faculty of Philosophy in Kosovska Mitrovica and describes the transformation process of the Contempory English Language 1 course drawing the comparison with the factors introduced in the previous section (policy, support, and evaluation). The blending of the learning environments, teaching and learning activities, or assessment details ${ }^{8}$ are not discussed here. It is only worthwhile to mention that the course was transformed into a blended course of the supplementary model ${ }^{9}$; online component of the course (40 hours of workload) was added to the unreduced seat-time prescribed by the syllabus.

As mentioned in the introduction, the implementation of BL at the Faculty of Philosphy was performed within the framework of the Tempus BLATT project. As the name of the project indicates, the advanced teacher training program implies that the academic staff involved in its realization is supposed to have prior knowledge of the principles and the experience in using the digital technology in teaching. The idea behind the project was to systematize the practice and to ground it in theories of learning (Tempus BLATT, 2013). Since this was the experimentation phase, there was no Faculty or University policy to regulate the implementation; the process of course transformation

8 For the details on the internal structure and the delivery of the course, see Janković \& Spasić, 2014

9 For the description of the different models of blended courses, see Peled, 2011. 
was managed by the strategy which was formulated within the project as a combined effort of the partner institutions to adapt their existing policies and best practices to our specific needs. ${ }^{10}$

The instructors were prepared for the transformation of the course and the implementation of the BL approach through both pre- and inservice training sessions in three critical categories: use of technology, re-design of the syllabus and learning outcomes, and the creation of the online content. The professional development program also included monthly consults with the instruction designers and the technology specialists during the delivery stage. All the consultation meetings were held via a web conferencing software, Adobe Connect; in additon, the sessions were recorded and made available online for later reference. Therefore, the professional (pedagogical) support of the teaching staff was well planned and executed as suggested in the literature review (Moskal et al, 2013; Jokinen \& Mikkonen, 2013; Porter et al, 2014). Furthermore, pre-service training sessions were open for public and advertised to the rest of the academic staff of the Factulty and the University, though the response and the participation was poor.

The online portion of the blended course was delivered via Moodle, the e-learning platform. Since there was no offical Moodle host for the Faculty of Philosophy or the University of Priština in Kosovska Mitrovica for that matter, we opted for the platform hosted by the Academic Network of Serbia, AMRES. ${ }^{11}$ Although it seemed as a perfect opportunity for the dissemination of the project results to use the national e-learning platform, there were two major issues with it. Primarily, the technical support for teachers and students was not readily and promptly available. The only means of communication with the tech support was via the native Moodle forum and it usually took several days to get a response. The workaround of the problem was to use the instructors as a technology help, while they were left to fend for themselves and find other creative ways of solving the issues. Unfortunately, in the first delivery in 2013, most of October was spent resolving registration and navigation issues instead of learning, just as Moskal et al. (2013) found happening in their study. This was, in part, remedied in the second delivery in 2014 by creating a comprehensive student guide to Moodle and FAQ section in the syllabus.

10 For more details, see the project website http://www.tempusblatt.pr.ac.rs/learning-inventory-framework.html

11 The AMRES platform is available at https://www.amres.ac.rs 
Secondly, the AMRES platform was heavily branded by the University of Belgrade whose Computer Centre supervised and managed the platform. Although the platform hosted well over hundred courses from all the universities in Serbia, it was difficult to assure the student buy-in in such an environment and with no course catalogue available beforehand as the course was delivered in the first semester (Hande, 2014; Harris et al, 2009; Sharpe et al, 2006). The motivation and active participation of the students were secured through engaging learning activities, extra-credit work, and active engagement of the instructors in the online discussion forums.

Another issue arose in the category of technical support of the BL implementation. The existing computer and Internet infrastructure at the Faculty was insufficient to underpin seamless delivery of the course (Romiszowski, 2004). Although the delivery was designed so that the online portion of the coursework was done outside the class time, the foundation of the design presumed available technical resources for the students to use to complete their learning activities (free Wi-Fi access and computer stations in the Faculty library). The Wi-Fi access points were limited to 15 users at a given time which caused constant crashes and limited connectivity because of the traffic volume; also, the two desktop computers in the library were heavily infected with viruses and adware.

The other obstacles we encountered in the delivery process were no different than those reported in the empirical studies (Ocak, 2011; Porter \& Graham, 2015; Sayed \& Baker, 2014; Shaqour, 2011; Tshabalala, 2014). Teacher burn-out rate was accelerated by managing different roles and shouldering increased work load. What is more, the class size increased almost double from 2013 to 2014. In addition, e-learning apathy was very common. Ocak (2011) describes it as the result of the management's unawareness of the benefits of e-learning and reluctance to invest resources, teaching staff's skepticisms and preference towards traditional teaching, and the students' lack of motivation and digital skills.

Therefore, the implementation of BL was performed with external pedagogical and technical support, existing technical infrastructure and no financial resources. In addition, the transformation process took place under the nominal support of the executive management but without the top-down coordination to ensure the sustainability of the practice. Our recommendation for the next steps is closely aligned with White's proposition for the executive management in the higher education: 
"[...] use sources of strategic funding to set up an institution wide approach of small, but systematic advances building upon existing pockets of excellence. Such an approach would answer the needs of the riskaverse mainstream for processes rather than projects, proven uses and strong vertical alignment of activities" (2007, p. 848).

\section{EVALUATION}

The Tempus BLATT project stipulated an elaborate procedure for assuring the course quality which was of paramount importance because we were treading the new and unfamiliar ground at the time. The process of the external evaluation of the course quality was organized in three stages: observation, self-evaluation, expert report and recommendations. The elements of the evaluation were: learning outcomes, curriculum design, teaching competencies, and facilities. During the delivery stage, an instructional designer and a technology specialist would have full access to the online component of the course to observe the teaching and learning activities. Personal information of the students was hidden from the observers; they would only be known by number designations (student 1 , student 2 , etc.).

In the post delivery stage, the teachers would submit self-evaluation reports to their designated pair of evaluators, who would schedule an interview with them and a selection of students after they studied the reports. These interviews were held and recorded via Adobe Connect. Finally, the evaluators would draft a report with recommendations for the improvement and send them to the teachers for their feedback. If possible, the teachers and the evaluators would "meet" again for the feedback session. Both deliveries of the blended course got excellent reviews:

"This course could be presented as a role model for all other courses at the University in terms of structure, clarity, media use, interactivity, and support" (Tempus BLATT, 2014, p. 75);

"Very good implementation that could stand as an example of good practice for other teachers. Good methodologies used where several adjustments have been made from experiences of earlier versions of the course, and with adjustments made also during this course" (Tempus BLATT, 2015, p. 9). 
Internal quality assurance was performed through a series of surveys. Primarily, students would complete weekly feedback polls with their impressions of the most or least useful activity that week and suggestions for change. Secondly, the mid-course feedback would be collected through a Moodle native survey, COLLES Actual ${ }^{12}$. Finally, end of the course evaluation was performed through a student satisfaction questionnaire ${ }^{13}$ which aimed at comparing the blended course to other courses the students were attending during the school year in terms of course organization, attainment of the learning outcomes, instruction and feedback, interaction, etc.

For the purpose of this paper, we present parallel results from the two deliveries (Table 1). Students were asked to qualify the internal logic of the course organization, to determine the appropriateness, helpfulness and promptness of the teachers' feedback, to ascertain whether they had enough meaningful practice to achieve the skills described in the learning outcomes, to confirm or deny whether the syllabus was easily accessible and comprehensive, and to express how easy was to navigate the virtual classroom. In the second part of the questionniare, we asked them to compare the opportunities they had in this course to the others they were attending at the same time:

- for interacting with the teachers and the peers;

- for accessing the course materials;

- for personal engagement and activity.

\begin{tabular}{l|cc}
\hline \multicolumn{1}{c|}{ CATEGORY } & $\begin{array}{c}\text { FEBRUARY 2013 } \\
\text { (35 STUDENTS) }\end{array}$ & $\begin{array}{c}\text { JUNE 2015 } \\
\text { (54 STUDENTS) }\end{array}$ \\
\hline Course organization & $91.7 \%$ & $95.4 \%$ \\
Instruction & $96.7 \%$ & $91 \%$ \\
Alignment & $94.6 \%$ & $94.6 \%$ \\
Syllabus & $98 \%$ & $100 \%$ \\
Ease of use (Moodle) & $80.6 \%$ & $90.9 \%$ \\
Interaction & $89.75 \%$ & $70.4 \%$ \\
\hline \hline
\end{tabular}

TABLE 1: PARALELl RESULTS OF THE STUDENT SATISFACTION SURVEY

12 For more information on the survey and the results in the first delivery, see Janković \& Spasić, 2014.

13 The questionnaire is available at http://bit.ly/StudentSatisfactionQuestionnaire 


\begin{tabular}{l|cc}
\hline Accessibility & $85.2 \%$ & $79.5 \%$ \\
Engagement & $88 \%$ & $72.8 \%$ \\
\hline
\end{tabular}

TABLE 1: PARALELl RESULTS OF THE STUDENT SATISFACTION SURVEY

The critical difference between the two deliveries, which might account for the unexpected drop in the student satisfaction, is the duration of the course. The 2013 course was delivered only in the first semester, while in 2014, when the newly accredited study program started, this course lasted for two semesters. The prolonged time of the delivery might account for the student e-apathy and their lesser satisfaction with teachers' instruction and interaction opportunities (Ocak, 2011). The lower degree of their satisfaction with personal engagement opportunities might be due to the increased number of students (Tshabalala, 2014).

One of the improvements suggested in the evaluation of the first delivery was to avoid copyright infringement by not offering scanned PDF versions of the course books to the students (Tempus BLATT, 2014). Therefore, the second generation of students only had original, teacher-made materials available online. The increased degree of the ease of use of the e-learning platform is/was due not only to higher digital competencies of the second generation of students, but also to a more comprehensive student guide which contained both written and video instructions in the second delivery as opposed to the first delivery where the issues were resolved as they would come along, most oftenly in the Help forum (Tempus BLATT, 2014). All in all, according to the students' comments at the end of the questionnaire, we can report their overall satisfaction with the blended format primarily because it provided them with additional opportunities to practice the course units, time to think and prepare an answer in the discussion forums, and ample additional materials to successfully complete the course.

As for the teachers' perceptions of the blended instruction, we administred the questionniare ${ }^{14}$ to determine how they felt during the process, what lessons they learned and what their recommendations would be for the novice teachers. The survey included nine teachers who participated in the implementation of the project, not just the teachers who delivered this course. The questionnaire was adminis-

14 The teacher perception questionnaire is available at http://bit.ly/ TeacherPerceptionQuestionnaire 
tered after the first delivery and the first cycle of the evaluation in May 2014.

All the teachers expressed mild satisfaction with the transformation process mostly impaired by the lack of student motivation and technical issues with the e-learning platform, though they would opt for the blended instruction again. When asked to compare the learning experience in the two approaches, only 2 out of 9 said that face-toface instruction suited them better. Considering the amount and the quality of the interaction, 100 percent reported that the BL approach offers more opportunities. The choice of e-learning platform was very dissatisfying for the quarter of the surveyed teachers, but they supplemented it with the use of social networking sites, mostly Facebook groups.

The survey showed consistent lack of any other digital tools used for learning, but the teachers expressed the willingness to learn how to utilize them in the future. This is consistent with their main complaint in the blended delivery. Namely, insufficient technical infrastructure and almost non-existent technical support proved detrimental to the overal learning experience and student motivation. However, they would all recommend the BL approach to their colleagues because it adds a new dimension to the traditional teaching, empowers students in their learning process, and gives a new perspective to the traditional teaching practice.

CONCLUSION The general objective of this paper was to survey the literature to establish elements of the successful institutional adoption of the blended learning approach and identify its advocates in higher education to ensure sustainability. Moreover, its specific objectives were to describe the conditions under which the approach was implemented at the Faculty of Philosophy in Kosovska Mitrovica and to give recommendations for its feasibility according to the established success factors.

In summary, the literature review identified three main instruments in the institutional acceptance of the digital innovation in teaching and learning: a) policy that ratifies and regulates the process; b) centralized system of technical, pedagogical, and administrational support; c) evaluation and assurance of quality and dissemination of results and best practices. Therefore, the advocacy begins at the top with the executive management but should also include the academic staff, student body, and the wider academic community. 
The case study showed absence of the significant aspects needed for the blended learning approach to become integral to our study programs at the Faculty. Namely, and understandably in the given circumstances, there was no Faculty policy to manage the implementation. Nominal top-down support left the instructors as the only advocates of the change. Furthermore, the existing technical infrastructure was inadequate to maintain the seamless and natural flow of teaching and learning. Finally, the increased teacher workload, which stemmed from the above mentioned circumstances, also impaired the delivery as seen from the comparison of the student satisfaction and the reported teachers' comments in the survey.

In conclusion, for the successful and sustainable institution-wide implementation of the BL approach at the Faculty of Philosophy, it is recommended to first plan the policy carefully and comprehensively by:

- identifying our needs and requirements (setting the context);

- defining the key concepts of blended learning (metalanguage);

- setting clear objectives and goals customized to our reality;

- assessing the required resources (financial, human, and technical).

Having in mind that these would be the first steps in the systematization of the approach, but not in the innovation of teaching, it is advisable to build upon the existing practice and experience of the academic staff. The findings suggest that the buildup should mainly be focused on designing an extensive and expert-led training program for the teaching and technical staff, as well as on upgrading the technical facilities.

Principally, more research into the many facets of the institutional adoption of BL is still necessary before those first steps could be made. It has been demonstrated that there is no instructional change without the teacher buy-in (Christo-Baker in Porter \& Graham, 2015). Therefore, the next stage of the study could be an extensive investigation into the expectations, perceptions, and motivation of the overall teaching staff in regards to the digital innovation.

Proofread for the use of English: Branislava Dilparić, Faculty of Philosophy, Kosovska Mitrovica. 
Abel, R. (2005). Achieving success in internet-supported learning in higher education: Case studies illuminate success factors, challenges, and future directions. Lake Mary, FL: The Alliance for Higher Education Competitiveness, Inc.

Janković, A.\& Spasić, D. (2014). Tackling Blended Learning at the Department of English in Kosovska Mitrovica. Sinteza: Impact of Internet on Business Activities in Serbia and Worldwide, 1(1), 412-417. Belgrade: Singidunum University.

De Vries, J. (2005). E-learning strategy: An e-learning framework for success. Blue Streak learning, quality learning solutions bottom line results. Retrieved October 12, 2015, from http://bit.ly/10NIpoN

Dziuban, C. D., Hartman, J. L., \& Moskal, P. D. (2004). Blended learning. EDUCAUSE Center for Applied Research Bulletin, 7(1), 12.

European Commision. (2013, November, 7). European Higher Education in the World [Brussels communique COM (2013) 499]. Retrieved October 12, 2015, from http://www.ipex.eu/IPEXL-WEB/dossier/document/COM20130499.do

Garrison, D. R., \& Kanuka, H. (2004). Blended learning: Uncovering its transformative potential in higher education. The Internet and Higher Education, 7(2), 95-105.

Graham, C. R. (2006). Blended learning systems. In CJ Bonk \& CR Graham, The handbook of blended learning: Global perspectives, local designs. Pfeiffer.

Hande, S. (2014). Strengths, weaknesses, opportunities, and threats of blended learning: Students' perceptions. Annals of Medical and Health Sciences Research, 4(3), 336-339.

Harris, P., Connolly, J.F., \& Feeney, L. (2009). Blended Learning: overview and recommendations for successful implementation. Industrial and Commercial Training, 41(3), 155-163.

Jokinen, P., \& Mikkonen, I. (2013). Teachers' experiences of teaching in a blended learning environment. Nurse Education in Practice, 13(6), 524-528.

Jovanović, A., Janković, A., Marković-Jovanović, S., Perić, V., Vitošević, B., and Pavlović, M. (2015). When Going Hybrid is not Enough: Statistical Analysis of Effectiveness of Blended Courses Piloted within Tempus BLATT Project. The International Journal of Education and Development using Information and Communication Technology, 11(2), 138-152.

Moskal, P., Dziuban, C., \& Hartman, J. (2013). Blended learning: A dangerous idea? Internet and Higher Education 18, 15-23.

Napier, N. P., Dekhane, S., \& Smith, S. (2011). Transitioning to blended learning: Understanding student and faculty perceptions. Journal of Asynchronous Learning Networks, 15(1), 20-32. 
Ocak, M. A. (2011). Blend or not to blend: a study investigating faculty members' perceptions of blended teaching. World Journal on Educational Technology, 2(3), 196-205.

Peled, Y. (2011, March 19). Models [weblog]. Retrieved October 18, 2015, from http://westminster-blended-learning.wikispaces.com/Models

Porter, W. W., \& Graham, C. R. (2015). Institutional drivers and barriers to faculty adoption of blended learning in higher education. British Journal of Educational Technology.

Porter, W. W., Graham, C. R., Spring, K. A., \& Welch, K. R. (2014). Blended learning in higher education: Institutional adoption and implementation. Computers \& Education, 75, 185-195.

Reimagining Teaching in a Blended Classroom [working paper]. (2014, November). The Learning Accelerator. Retrieved October 2, 2015, from http:// learningaccelerator.org/reimagining-teaching-in-a-blended-classroom

Romiszowski, A. J. (2004). How's the e-learning baby? Factors leading to success or failure of an educational technology innovation. Educational Technology, 44(1), 5-27.

Royal, K. D., Smith, K. W., Foster, J. H., \& Hedgpeth, M. W. (2014). You say tomato, I say "tomahto": Semantics of blended learning. Medical Science Educator, 25(1), 81-82.

Sayed, M. \& Baker, F. (2014). Blended learning barriers: An investigation, exposition, and solutions. Journal of Education and Practice, 5(6), 81-86.

Shaqour, A. Z. (2014). Faculty members' views towards blended learning: Case of a Najah National University master program Teachers in the College of Education and Teacher Preparation. International Journal of Humanities and Social Science, 4(7), 99-106.

Sharpe, R., Benfield, G., Roberts, G., \& Francis, R. (2006). The undergraduate experience of blended e-learning: a review of UK literature and practice. The Higher Education Academy.

Tempus BLATT. (2013). Project summary [Brochure]. Retrieved March 7, 2014, from http://issuu.com/tempus_blatt/docs/tempus_blatt_project _summary

Tempus BLATT. (2014). Contemporary English Language 1 [Report]. Pilot Course Review, 63-76. Retrieved October 20, 2015, from http://issuu.com/ tempus_blatt/docs/blatt_course_review_report/1

Tempus BLATT (2015). Contemporary English Language 1 [Report]. Course review, 7-12. Retrieved October 20, 2015, from http://issuu.com/tempus_blatt/ docs/course_review_2015 
Thurab-Nkhosi, D. (2013). Blended learning at The University of the West Indies, St Augustine: A first look at policy implementation. Caribbean Teaching Scholar, 3(1), 81-92.

Torrisi-Steele, G. (2011). This thing called blended learning - a definition and planning approach. Research and Development in Higher Education: Reshaping Higher Education, 34, 360-371.

Tshabalala, M., Ndeya-Ndereya, C., \& van der Merwe, T. (2014). Implementing blended learning at a developing university: Obstacles in the way. Electronic Journal of e-Learning, 12(1), 101-110. Retrieved October 18, 2015, from http://www.ejel.org/issue/download.html?idArticle=271

White, S. (2007). Critical success factors for e-learning and institutional change - some organisational perspectives on campus-wide e-learning. British Journal of Educational Technology, 38(5), 840-850. 
АНИТА В. ЈАНКОВИК

УНИВЕРЗИТЕТ У ПРИШТИНИ С ПРИВРЕМЕНИМ СЕДИШТЕМ

У КОСОВСКОЈ МИТРОВИЦИ, ФИЛОЗОФСКИ ФАКУЛТЕТ

РЕЗИМЕ

УЗРОЦИ НЕУСПЕХА ХИБРИДНОГ УЧЕЬА НА ФИЛОЗОФСКОМ ФАКУЛТЕТУ У КОСОВСКОЈ МИТРОВИЦИ: СТУДИЈА СЛУЧАЈА

Овај рад је кроз преглед литературе представио битне факторе и најчешће препреке успешној примени хибридног учења у високом образовању. Три главне категорије фактора успеха су: а) стратегија која регулише примену хибридног учења; $\delta$ ) систем административне, педагошке и техничке подршке; в) вредновање и осигурање квалитета наставе и дисеминација добијених резултата. С друге стране, најчешће препреке у остваривању технолошке иновације у високом образовању су: повећани обим рада наставника, неодговарајућа техничка инфраструктура, смањена мотивација студената, непостојање административне подршке од стране управе, и сл. Добијена листа фактора послужила је за мерење услова у којима је хибридно учење реализовано на Филозофском факултету у Косовској Митровици.

Систематска примена концепта хибридног учења на Филозофском факултету у Косовској Митровици почела је у октобру 2013. године у оквиру пројекта Темпус БЛАТТ. Реализација је обављена током две узастопне школске године на предмету Савремени енглески језик 1 који похађају студенти прве године на Катедри за енглески језик и књижевност. План и програм овог предмета представља мешавину наставних метода и стилова учења у строго контролисаној средини где се избор електронских алата за учење надовезује на традиционалне наставне методе.

Аутор је затим представио резултате процеса евалуације која је имала за циљ да установи квалитет хибридних курсева, степен задовољства студената новом организацијом наставе и ставове наставника и њихова искуства у примени овог приступа. Коначно, рад препоручује истраживање које ће имати за циљ да мапира ставове, мотивацију и очекивања наставног особља у вези са употребом дигиталне технологије у настави.

КљУчнЕ РЕчи: хибридно учење, институционална подршка, одрживост, фактори успеха, препреке, трансформација, вредновање. 